\section{The rental system in Ghana's low-income housing communities, challenges and adaptation strategies}

\section{Peter Kwame Achamwie \& Esther Yeboah Danso-Wiredu}

\section{Research article}

DOI: http://dx.doi.org/10.18820/2415-0495/trp79i1.8

\section{Received: July 2021}

Peer reviewed and revised: October 2021

Published: December 2021

*The author(s) declared no potential conflicts of interest with respect to the research, authorship, and/or publication of this article

\begin{abstract}
Shelter is one of the fundamental needs of human survival aside food and clothing. However, provision of adequate housing to accommodate people in urban areas has been a challenge in developing countries, including Ghana. This has caused many Ghanaians, especially the low-income group, to resort to the rental sector for their housing needs. It is widely discussed in the literature that each city user is to be accorded the needed right to utilise what exists in the city, including decent accommodation. This article examines the strategies put in place by lowincome house tenants to cope with the challenges of renting houses in the Wenchi Municipality, in order to rightly utilise urban housing. The study used a quantitative approach and a questionnaire survey to collect data from 245 tenant household heads. Purposive and systematic sampling techniques were used to select the respondents for the study. The data was analysed using SPSS. The study revealed that rental problems faced by tenants and adaptation measures developed to cope in cities and bigger towns are not different from what exists in the smaller towns. The study recommended that rent control should be strengthened to perform its duties in the rental sector well enough to protect the interest of the urban low-income renters.
\end{abstract}

Keywords: Challenges, low-income housing, low-income tenants, housing quality, rental accommodation, rental system, Wenchi, Ghana

\section{DIE HUURSTELSEL IN GHANA SE LAE-INKOMSTEBEHUISINGSGEMEEN SKAPPE, UITDAGINGS EN AANPASSINGSTRATEGIEË}

Afgesien van kos en klere is skuiling een van die fundamentele behoeftes vir menslike oorlewing. Die verskaffing van voldoende behuising om mense in stedelike gebiede te akkommodeer bly 'n uitdaging in ontwikkelende lande insluitend Ghana. Dit het veroorsaak dat baie Ghanese, veral die lae-inkomstegroep, na die huursektor oorgegaan het vir hul behuisingsbehoeftes. Dit word wyd in die literatuur bespreek dat elke stadsgebruiker die nodige reg moet kry om dit wat in die stad bestaan, te benut, insluitend ordentlike akkommodasie. Hierdie artikel ondersoek die strategieë wat deur lae-inkomstehuishuurders ingestel is om die uitdagings van die huur van huise in die Wenchi Munisipaliteit die hoof te bied om sodoende stedelike behuisingsreg te benut. Die studie het 'n kwantitatiewe benadering en 'n vraelysopname gebruik om data van 245 huurderhuishoudings in te samel. Doelgerigte en sistematiese steekproeftegnieke is gebruik om die respondente vir die studie te selekteer. Die data is met SPSS ontleed. Die studie het aan die lig gebring dat huurprobleme en aanpassingsmaatreëls wat ontwikkel is om hierdie probleme in stede en groter dorpe die hoof te bied, nie verskil van probleme wat in die kleiner dorpe bestaan nie. Die studie het aanbeveel dat huurbeheer versterk moet word om sy pligte in die huursektor goed genoeg uit te voer om die belange van die stedelike lae-inkomste huurders te beskerm.

Sleutelwoorde: Behuisingskwaliteit, huurakkommodasie, huurstelsel, laeinkomste behuising, lae-inkomste huurders, uitdagings, Wenchi, Ghana

\section{TSAMAISO, LIPHEPHETSO LE MAANO A KHIRISO EA MATLO METSENG EA GHANA}

Ka thoko ho lijo le liaparo, bolulo ke e 'ngoe ea litlhoko tsa mantlha tsa botho. Leha ho le joalo, hona le phephetso e kholo ea tokisetso ea bolulo ba batho litoropong tsa linaheng tse futsanehileng, tse akhang Ghana. Sena se entse hore batho ba bangata ba Ghana, haholoholo ba fumanang meputso e tlaase, ba ikhethele ho hira matlo ele ho arabela thoko ea bona ea bolulo. Lingoliloeng tse ngata li bontsha hore mosebelisi e mong le e mong oa toropo o lokela ho fuoa tokelo ea manthla ea ho sebelisa se teng toropong, ho kenyeletsoa le sebaka sa bolulo. Sengoliloeng sena se hlahloba kamoo bahiri ba matlo a lipehelo tse tlase ba sebetsanang le liqholotso tsa matlo a hirisoang Masepaleng oa Wenchi. Boithuto bona bo sebelisitse mokhoa oa lipalo-palo (quantitative) le thahlobo ea lethathamo la lipotso ho bokella lintlha. Lipotso li ile tsa lebisoa ho lihlooho tsa malapa tse 245 tse hirileng matlo a lipehelo tse tlase Masepaleng ona. Boithuto bo khethile lihlooho tsena ho latela bohlokoa ba bona le tsebo ea bona boithutong bo etsoang. Linthla tseo ba 
faneng ka tsona li ile tsa hlahlojoa ho sebelisoa SPSS. Phuputso e senotse hore ha hona phapang ea mathata a khiriso ea bolulo a tobaneng le bahiri le mekhoa e'o ba rarollang mathata ana ka ona lipakeng tsa litoropo le litorotsoana. Boithuto bona bo khothalelitse hore taolo ea rente e matlafatsoe ele ho sireletsa bahira ba futsanehileng litoropong.

\section{INTRODUCTION}

Shelter is one of the fundamental needs of human survival aside food and clothing. However, the provision of adequate housing to accommodate people, especially the urban poor, has been challenging (Bujang, Afrane, Ariffian, Shuaibu \& Kasim, 2016: 18). The acute shortage of housing is a principal issue for all, especially low-income earners (Aboagye \& Sarpong-Kumankoma, 2011: 17). This is so because many nations, especially sub-Saharan Africa nations, have over the years experienced high urban population growth and high housing demands against inadequate supply (Magina, 2016: 24). As a result, more lowincome earners are becoming homeless, thus forcing them to adopt slums and squatter settlements as an option in most of the cities and towns (Serageldin et al., 2003, cited in Danso-Wiredu \& Midheme, 2017: 14). A report by the United Nations (UN) estimates that the urban population will increase to roughly five billion by 2030 , due to high population growth (Kojo \& Paschal, 2018: 23). It is also projected that, by 2021 , approximately thirty-five million housing units will be needed on an annual basis to cater for newly formed households and the replacement of weak ones in the urban centres (Dzangmah, 2012: 11).

Research by Chiwenga (2019: 29) indicates that housing provision for the low-income groups has been a global challenge, as many cities and towns are unable to provide adequate housing to the urban poor, due to budgetary constraints. The pressure is more pronounced in subSaharan Africa (Appiah-Kusi, 2015: 25). This leads to the development of unplanned spatial activities in many cities (Appiah-Kusi, 2015: 15).
In the context of Ghana, house ownership involves a huge capital investment and serves as an indelible mark for individuals and property for the family. Due to this, housing, which is supposed to be a basic need, sometimes becomes a luxury, because many are unable to acquire it (Dzangmah, 2012: 31). Research has revealed that the vast majority of Ghanaians, especially the low-income earners, find it difficult to access decent accommodation (Aboagye \& Sarpong-Kumankoma, 2011: 30). A revealing report from the Ministry of Water Resources, Works and Housing (MWRWH) indicates that Ghana is having a huge deficit of approximately 1.7 million housing units (MWRWH, 2015). The report alluded to the fact that about $35 \%$ and $85 \%$ of Ghanaians do not have the financial capacity to afford a house beyond GHS12 000 and GHS72 000, respectively. ${ }^{1}$ Areas that are much threatened include Accra, Kumasi Takoradi, and Tamale. Due to rural-urban migration, these cities are always overwhelmed with population, making access to accommodation difficult (Owusu-Ansah, 2012: 29; DansoWiredu, 2018: 19). Due to financial difficulty, most of the low-income earners have become homeless, thus compelling them to opt for slums and squatter settlements as options in most of the cities and towns (Serageldin et al., 2003, cited in Danso-Wiredu \& Midheme, 2017: $6)$. It is also revealing to note that some low-income urban dwellers live in small-sized single rooms, with those from extremely poor economic status migrants either sharing or staying with friends or relatives (Yankson, 2012: 12; Ofori, 2020).

Many studies have been conducted on poor housing in Ghana, mostly concentrating on the bigger towns and cities (Owusu, 2010: 9; Yankson, 2012: 15; Adu, Abedi, Gyan \& Janneth, 2016: 21; Danso-Wiredu, 2018: 13; Wrigley-Asante, Frimpong, Amu, Owusu \& Oteng-Ababio, 2019: 19; Ofori, 2020). These studies usually neglect rural, smaller towns and pre-urban areas, where similar challenges exist, thus creating a gap

1 In 2015, $1 \mathrm{GHS}$ was to 0.3 USD in study. In this regard, this article focuses on Wenchi, a smaller town in Ghana, to argue that the challenges and adaptation measures employed by low-income urban tenants exist in both bigger and smaller towns.

\section{LITERATURE REVIEW}

\subsection{Rental housing in Ghana}

According to Ofori (2019: 169), rental accommodation has been acknowledged as an alternative method to address the housing predicament in sub-Saharan countries, specifically Ghana. Research has shown that, in Ghana, about one in every four households owns its own accommodation, while the remainder either rent or live in rent-free family houses with others living in slums (UN-Habitat, 2011). There are four types of rental housing providers: individuals or small-scale suppliers (UN-Habitat, 2003: 107), medium- and large-scale institutional owners and investors (Peppercorn \& Taffin, 2013: 9); social housing (Peppercorn \& Taffin, 2013: 9), and public sector housing suppliers (Gilbert, 2004). In Ghana, like in many other African countries, rental housing is normally found among private rental individuals (landlords or small-scale suppliers). Some unique characteristics of this type of suppliers is that rent prices are fairly low compared to the other groups. Often, suppliers live with the tenants in the same house (UN-Habitat, 2003). Peppercorn and Taffin (2013: 9) state that these groups of owners mostly consist of informal rent owners, because many of the landlords keep their properties off the books to avoid payment of taxes. Government have been taxing rental income higher than 'earned' income (UN-Habitat, 2011: 2).

Rental housing serves as a source of income and security for landlords, and offers an affordable accommodation choice for renters, especially workers and vulnerable households (Lonardoni \& Bolay, 2016). At the national level, rental accommodation helps relieve the challenges in housing provision in many countries, especially in 
developing countries including Ghana (Ofori, 2019: 169). Despite this reality, the credibility of renting and multi-occupancy as alternative tenure options is ill-recognised by the government of Ghana as the effectiveness of the Rent Control Department (RCD) of Ghana is very minimal (Nsiah, 2017: 56). The RCD was established to create an enabling environment for all citizens to access decent and affordable accommodation, in order to promote the socio-economic development of Ghana. Such interventions have, however, failed to impact positively on the poor majority who still occupy single rooms with shared or no services (UN-Habitat, 2011: 2).

Charles-Coll (2011: 19) points out that access to decent housing undoubtedly serves as a key determinant of human survival. This is so because, in the absence of decent accommodation, all other activities engaged by man for survival will come to a halt. Article 18 of the 1992 Constitution of Ghana states categorically that the right to decent accommodation is highly linked to the citizen right to enjoy other basic human rights such as security/safety, privacy, education, and health. This is, however, not so in reality. The 2010 population and housing census report revealed that many renters in Ghana are deprived of these basic facilities, although they pay huge sums of money (GSS, 2014: 45). These challenges are attributed to many factors.

\subsection{Challenges with rental housing among low-income communities}

\subsubsection{Rent affordability and system of payment}

Rental affordability is ultimately an elusive concept that demands subjective judgements about how much income is too much to spend on housing (Belsky \& Drew, 2007). The living standard of the vast majority of households among lowincome earners keeps deteriorating, because, after paying for rent, they are unable to afford other necessities such as proper healthcare, good nutrition, sanitation, and education
(Hyde, 2018: 9). In Ghana, payment for rent is known as 'advance rent' - a practice that is incoherent with the Rent Act in Ghana (Arku, Luginaah \& Mkandawire, 2012: 3177). Homeowners or landlords in Ghana, for instance, typically require private renters to pay a huge sum of money of about two to five years' advance for the rental unit and failure of the tenants to pay this advance rent will result in the eviction of the affected tenants (Addo, 2016: 631). In the private informal rental housing sector, landlords/ ladies rarely record their tenancy agreements formally and most of them do not provide receipts (Arku et al., 2012). Due to the absence of a legal agreement between most of the tenants and landlords, landlords evict tenants within their own power; the constant anxiety about tenants being evicted contributes to stress and ill-health (Luginaah, Arku \& Baiden, 2010: 529).

\subsubsection{Housing quality}

Ballesteros (2004) noted that the quality of rental housing is largely a function of rent levels - meaning that low rents provide poor housing quality. Several factors such as materials of the outer walls, type of water services, type of sewage services, tenure and food markets, public transportation, schools, and the availability of health clinic/ hospitals influence housing quality (UN-Habitat, 2003). Inadequate maintenance and housing conditions such as electrical faults, exposed roofs, and cracked walls, if not maintained, expose tenants living in the affected houses to danger. Landlords who live in the same house with the tenants do maintenance on time (UN-Habitat, 2003), but tenants are sometimes made to do maintenance work on their own or share costs for maintenance work to be done in their houses and rooms. UN-Habitat (2003) and Addo (2016: 631 ) identify overcrowding in most of the rental housing units, especially in low-income communities. To reduce costs, some households live in substandard housing and share with others residences too small to effectively meet their needs (Belsky \& Drew, 2007).

\subsubsection{Inadequate facilities and services}

In Ghana, the vast majority of rental houses occupied by low-income renters are associated with a lack of basic housing infrastructure and have poor housing facilities (Ofori, 2020). Tenants are inconvenienced when facilities such as toilets, bathrooms, pipes, and kitchens are not available or are not located in the house (Amenyah \& Fletcher, 2013: 39). Many rental houses in Ghana's low-income communities are characterised by poor sanitation, poor drainage, and poor waste management practices (Amenyah \& Fletcher, 2013: 40). These challenges tend to have negative effects on the health of affected tenants. Usually, the outbreak of diseases such as cholera, diarrhoea, and malaria is associated with poor housing sanitation (Mara, Lane, Scott \& Trouba, 2010). In houses where tenants are not in proximity of their places of employment, transport, schools, healthcare, markets, places of worship and other neighbourhood social infrastructure, tenants are faced with the challenge of travelling over a long distance to enjoy such facilities (UN-Habitat, 2003).

\subsubsection{Security and safety}

Research has asserted that both physical and socio-economic decay in many low-income areas has led to an increase in both petty and organised crime by some youth in Ghana (Oteng-Ababio, 2016: 51). Pickpocketing, armed robbery, occultism (also termed "sakawa", with the intention of inducing their victims to comply to their demands) (Oduro-Frimpong, 2011) have led to increasing safety concerns among vulnerable groups such as women, the elderly and even strangers in such communities (Wrigley-Asante, Owusu, Oteng-Ababio \& Owusu, 2016). Research on safety in Ghana by Wrigley-Asante et al. (2019) has shown that $93 \%$ of the respondents who took part in the study stated that they had been victims of crime at popular places such as transport terminals, public toilets, and at places where there is no street light at night. Adu et 
al.'s (2016) study has shown that dwellings without secure doors, walls, windows, or other security features afford robbers the opportunity to attack people. In addition, the weak nature of most of the structures occupied by low-income households includes incomplete and dilapidated buildings that are usually not safe in terms of natural disasters such as flooding and fires.

\subsubsection{Privacy}

Within the context of housing and overcrowding among low-income house renters in Ghana, many individuals may not be able to sustain personal space and privacy, due to limited living space (Yankson, 2012; Danso-Wiredu, 2018; WrigleyAsante et al., 2019; Ofori, 2020: 14). Occupancy of more than three persons per room is not standardised by UN-habitat (Ofori, 2020: 14). Where six or more people stay in one single room, there is no right to privacy. Adu et al.'s (2016) research has demonstrated that, where bathroom and toilet facilities are not provided, tenants in low-income housing resort to bathing outside and exposing themselves in public.

\subsubsection{Health issues}

Tenants in overcrowded accommodation or housing with shared facilities put themselves at greater risk of getting infectious diseases such as meningitis, tuberculosis, and scabies and opportunistic infections such as HIV and AIDS (Graham, Emerson, Hatton, Llewellyn \& Blacker, 2006: 862; Krieger \& Higgins, 2002: 758). Cooper and Jones (2008: 261) established that overcrowding and other poor household environments contribute to mental stress and reduce people's sense of general well-being. People in low-income areas suffer from malaria, diarrhoea, cholera, and acute respiratory diseases because of poor sanitation or lack of sanitation and no proper garbage disposal (De Vet, Van Luijtelaar, Brilleslijper-Kater, Vanderplasschen, Beijersbergen \& Wolf, 2013). Dumping of waste, including raw sewage in drains and open gutters as means of garbage disposal results in choked drains with stagnant water serving as breeding grounds for mosquitoes/malaria (Mohammed \& Williams, 2013: 1152).

\subsection{Strategies to survive rental housing in low-income housing communities}

Morris and Winter's (1975: 27) theory of family housing adjustment is adapted for this study. The model explains that the way in which a society is structured determines how families are housed, its consequences for families as well as the decisions families make (Morris \& Winter, 1978: 25) on the physical arrangement of the house. According to the theory, the family seeks five norms in the family housing adjustment process: housing space norms - when adjustment is made on residential spaces to create extra spaces for activities such as cooking, sleeping and bathing; tenure norms - ownership or renting of the houses; structure type norms - examples could be single family apartment, compound, detached and semi-detached; quality norms deals with the extent of satisfaction, this is usually subject to family demands and expectations, and the neighbourhood and location norms - the community's comportment and the extent of relationship among community members. It also includes community infrastructure development such as road networks, health and educational facilities.

The theory also examines the different forms of adjustments that household or family members can make, in order to re-design their house to suit their needs. This article adopts the residential adaptation adjustment. This refers to the various activities in which household members can engage to make their house fit their needs (Sinai, 2001: 23; Imrie \& Hall, 2003: 27). These include additions, alterations, remodelling and changing the functions of rooms (Hawkins \& Stewart, 2002: 21). This study adapts the residential adaptation model to mean what different households living in a rented accommodation do to adjust the housing physical arrangements or the changes in social arrangement that make them fit to use their rented structures in the study communities. The more comprehensive models of housing adjustment include both moving and non-moving adjustment mechanisms (Sinai, 2001: 30; Quercia \& Rohe, 1993: 20). This study, however, dwells on the non-moving adjustment mechanisms tenants adopt. It is common for renters to add household facilities such as toilets or kitchens to their rented houses or, in some instances, they change the usual design of the house for different uses. For example, converting porches and kitchens into sleeping places. In situations where the family does not have the resources to effect such changes, other alternative measures are taken, including children sleeping with their friends or other relatives at night. Urban dwellers take these measures in order to utilise their right to the city.

\section{STUDY AREA}

The research was conducted in the Wenchi Municipality, the capital of the Bono region (see Figure 1), which is one of sixteen administrative regions in Ghana. Wenchi is roughly $30 \mathrm{~km}$ north of Techiman and approximately $50 \mathrm{~km}$ east of the Ivory Coast border, with a population of roughly 108890 (Ministry of Finance, 2018: 45). ${ }^{2}$ In 2013, the population totalled 39187 . The Municipality is predominantly rural and is noted for its arable food crops production. Over half $(57.8 \%)$ of the people are engaged in agriculture (GSS, 2012: 57). The major crops grown are yam, maize, cassava, cocoyam, plantain as well as vegetables such as tomatoes, aubergines, onions, and okra. Cashew and mangoes are also grown on a large scale. The Municipality has 11048 houses, with 88209 households and accommodates eight persons on average per house (GSS, 2012: $47)$. Half $(50.6 \%)$ of all housing in the municipality are compound houses; $32.4 \%$ are separate houses, and $7.4 \%$ are semi-detached houses (GSS, 2012: 47). Nearly half $(49.7 \%)$ of the housing units in the

2 The 2021 population census data was not yet available at the time of publishing this article. 


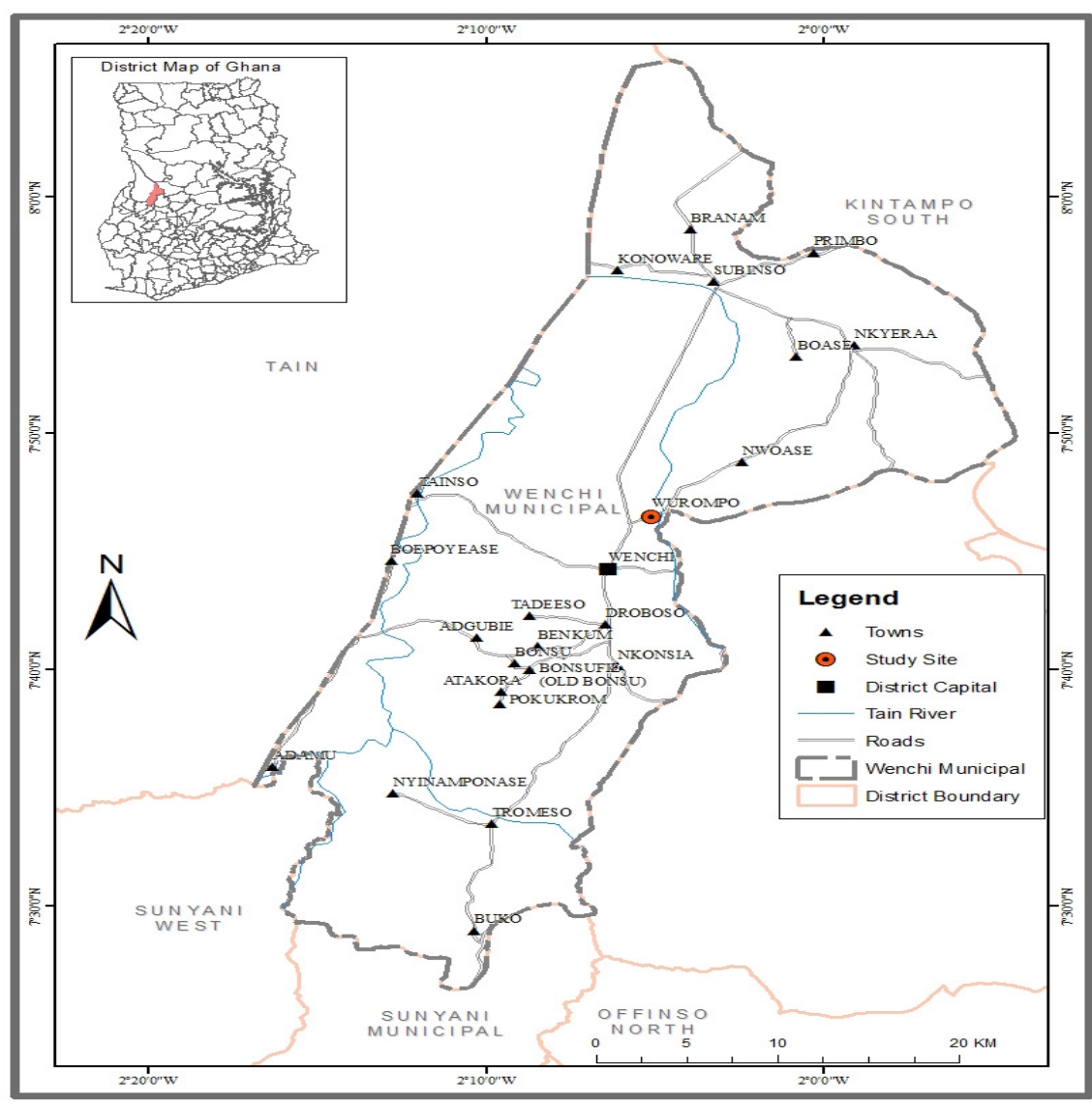

Figure 1: Map of Wenchi municipality

Source: $\quad$ Author, derived from Arg GIS, 2021

municipality are owned by members of the household; $26.9 \%$ are privately owned, and $19.5 \%$ are owned by relatives who are not members of the household (GSS, 2012: 2).

\section{METHODOLOGY}

\subsection{Research approach}

This article examines the strategies put in place by low-income house tenants to cope with the challenges of renting houses in the Wenchi Municipality, in order to rightly utilize urban housing. The researcher used a quantitative semi-structured questionnaire survey to collect information, because it allows for generalisation of findings across a population (Bryman, 2012: 232; Eyisi,
2016: 21). This approach also allows for the use of descriptive statistics.

\subsection{Population and sampling}

For the communities Akrobi, Jensoso and Zongo, the Wenchi Municipality has a population of 89,730 , with a rental household of 2924 and a housing stock of 11,048 (GSS, 2014). Due to the large size of the target population, systematic random sampling was used to select every fifth house from the 2458 houses, resulting in 492 houses. From the house sample, convenient sampling techniques were used to select 245 tenant household heads from the study area (see Table 1). Convenient sampling was appropriate because of the availability and readiness of the respondents to participate in

Table 1: Population and sample

\begin{tabular}{|l|c|c|c|c|c|}
\hline \multicolumn{1}{|c|}{ Community } & Total population & Households & Houses & House sample & Household sample \\
\hline Zongo (migrant) & 4650 & 1074 & 905 & 181 & 84 \\
\hline Jensoso (indigenous) & 5356 & 1005 & 945 & 189 & 94 \\
\hline Akrobi (mixed) & 3852 & 845 & 608 & 122 & 67 \\
\hline Total & 13858 & 2924 & 2458 & 492 & 245 \\
\hline
\end{tabular}

the study. It must be acknowledged that 245 tenant household heads were selected for the study, because most of the houses had more than one household.

Sampling was done, using the recommended sample size table of Krejcie and Morgan (1970: 608). From the Table, the recommended sample size for a population of 2400 is 248 , and for 500, 145. This recommendation validates the sample size of 492 and 245 as efficient for the housing population of 2458 and household head population from the house sample of 492 in Table 2. All questionnaires were retrieved, resulting in a $100 \%$ response rate.

\subsection{Data collection}

The study used a questionnaire survey to collect data from the household heads between 15 May 2020 and 30 June 2020. The questionnaire was composed of multiple closed-ended questions containing items of different format. The questionnaire consisted of three sections. The first section, on the respondents' demographic profile, obtained personal information on age and education, length of stay, and housing type. The second section set eight tick-box statements (with options) to indicate the challenges of renting houses in the Wenchi municipality. Household heads were asked to indicate concerns related to security, services, price, facilities, housing size and quality, sanitation, waste disposal, and privacy. The third section contained 4 tick-box options, each to determine the strategies that housing tenants use to cope with the challenges in rental accommodation in the Wenchy Municipality. The results from these measurements form the items used in the descriptive analysis (Naoum, 2013: 39).

\subsection{Data analysis}

In analysing the data, responses from the completed questionnaires were computed, using the Statistical Package for Social Science (SPSS) version 25 (Pallant, 2013). The frequencies and/or percentages of responses were generated and reported, in order to analyse 
the respondents' profile, their perceptual views on challenges, and their coping strategies.

\section{FINDINGS, RESULTS AND DISCUSSION}

\subsection{Respondents' profile}

Table 2 shows the participants' demographic and housing profile. In all the communities, the vast majority $(69.4 \%)$ of the participants were aged between 30-49 years, of which Akrobi had the highest number $(44.8 \%)$ of tenants who fall within the age range $30-39$ years and Jensoso has the largest number $(57.4 \%)$ who fall within the age range 40-49 years. Of the respondents, $49.4 \%$ either attended junior high school $(29.0 \%)$ or senior secondary school (20.4\%); $39.1 \%$ did not attend school. The vast majority $(62.4 \%)$ of the tenants rent compound houses and have lived four years or more $(46.1 \%)$ in their house.

Table 2 shows different types of house units in the selected study areas within the Wenchi Municipality (see Figure 2). Although 15.5\% of the participants live in semi-detached

Table 2: Respondents' demographic and housing profile

\begin{tabular}{|c|c|c|c|c|c|c|c|c|c|}
\hline \multirow[b]{2}{*}{ Characteristic } & \multirow[b]{2}{*}{ Category } & \multicolumn{2}{|c|}{ Akrobi } & \multicolumn{2}{|c|}{ Jensoso } & \multicolumn{2}{|c|}{ Zongo } & \multicolumn{2}{|c|}{ Total } \\
\hline & & $\begin{array}{c}F \\
(N=67)\end{array}$ & $\%$ & $\begin{array}{c}F \\
(N=94)\end{array}$ & $\%$ & $\begin{array}{c}F \\
(N=84)\end{array}$ & $\%$ & $\begin{array}{c}F \\
(N=245)\end{array}$ & $\%$ \\
\hline \multirow{5}{*}{ Age (years) } & $20-29$ & 11 & 16.5 & 6 & 6.4 & 4 & 4.8 & 21 & 8.6 \\
\hline & $30-39$ & 30 & 44.8 & 18 & 19.0 & 23 & 27.4 & 71 & 29.0 \\
\hline & $40-49$ & 20 & 29.9 & 54 & 57.4 & 25 & 29.8 & 99 & 40.4 \\
\hline & $50-59$ & 6 & 9.0 & 15 & 16.0 & 13 & 15.5 & 34 & 13.9 \\
\hline & $60+$ & 0 & 0.0 & 1 & 1.1 & 19 & 22.6 & 20 & 8.1 \\
\hline \multirow{5}{*}{ Education } & None & 14 & 20.9 & 41 & 43.6 & 41 & 48.8 & 96 & 39.1 \\
\hline & Junior high school & 17 & 25.4 & 31 & 33.0 & 23 & 27.4 & 71 & 29.0 \\
\hline & $\begin{array}{l}\text { Senior secondary } \\
\text { school }\end{array}$ & 19 & 28.4 & 13 & 13.8 & 18 & 21.4 & 50 & 20.4 \\
\hline & Diploma & 11 & 16.4 & 9 & 9.6 & 1 & 1.2 & 21 & 8.6 \\
\hline & Tertiary & 6 & 8.6 & 0 & 0 & 1 & 1.2 & 7 & 2.9 \\
\hline \multirow{4}{*}{ Housing type } & Compound & 35 & 53.3 & 46 & 54.7 & 72 & 76.6 & 153 & 62.4 \\
\hline & Local mud/bricks & 2 & 3.0 & 15 & 4.8 & 7 & 7.4 & 24 & 9.8 \\
\hline & Semi-detached & 26 & 38.8 & 4 & 17.9 & 8 & 8.5 & 38 & 15.5 \\
\hline & Detached & 4 & 6.0 & 19 & 22.6 & 7 & 7.4 & 30 & 12.2 \\
\hline \multirow{3}{*}{$\begin{array}{l}\text { Duration of } \\
\text { stay in rental } \\
\text { housing }\end{array}$} & $<1$ year & 18 & 26.9 & 18 & 19.1 & 23 & 27.3 & 59 & 24.1 \\
\hline & 2-4 years & 13 & 19.4 & 35 & 37.2 & 25 & 29.8 & 73 & 29.8 \\
\hline & 4 years or more & 36 & 53.7 & 41 & 61.2 & 36 & 42.9 & 113 & 46.1 \\
\hline
\end{tabular}

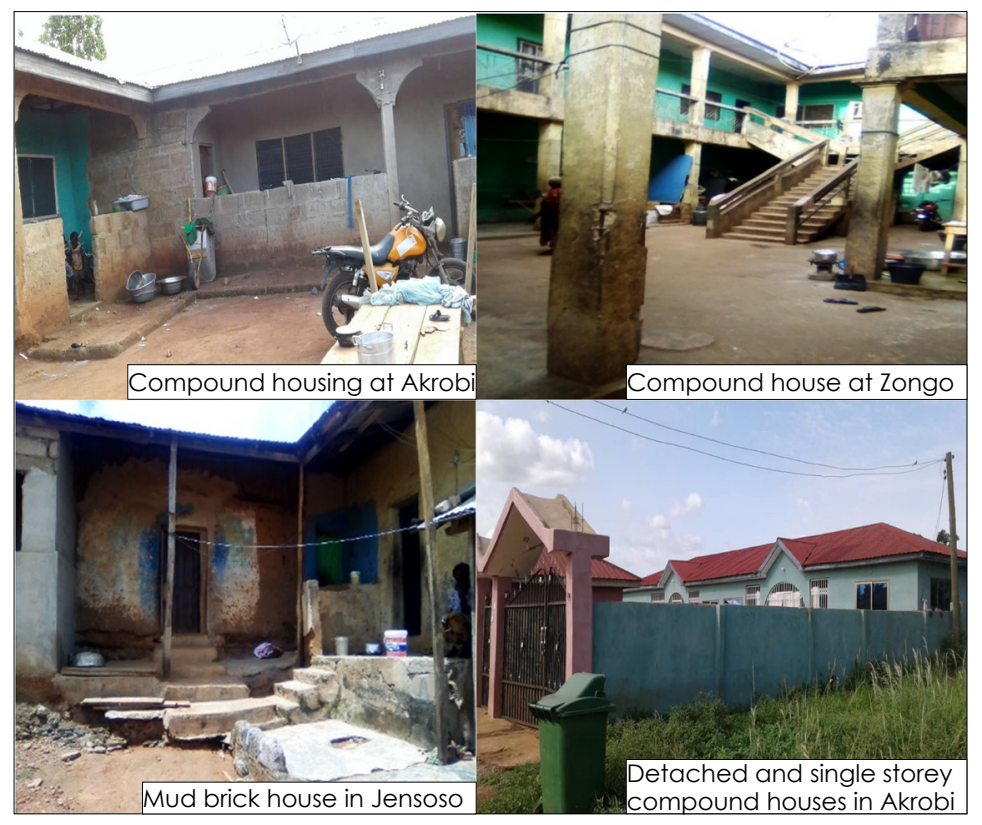

Figure 2: Housing typologies in the study communities

Source: Images taken by first author, 2020

houses, the vast majority (62.4\%) of them live in compound houses; $9.8 \%$ live in mud/brick houses. In this article, a compound house is a complete house (either single- or twostorey) buildings with several rooms, where tenants mostly share facilities and a common yard; tenants and their landlords stay together; facilities are either shared or exclusively used depending on the tenant/landlord agreement. Although compound housing is the vast majority $(76.6 \%)$ in the Zongo community, makeshift structures such as kiosks and containers also prevail. Semidetached housing units are mostly rented by lower middle-income households. The tenants sometimes live in self-contained structures, i.e. rooms with kitchen, toilet and bathroom attached, although, in the study communities, most of the tenants in such rooms share toilets and bathrooms with other tenants in the houses. Although only $9.8 \%$ of the respondents stay in mud/brick houses, they are the most vulnerable in the various communities.

The findings affirm Danso-Wiredu (2017: 14); Andreasen \& Andersen (2006: 411); Danso-Wiredu and Poku (2020: 1019); Yankson \& Gough (2014: 411), and Addo (2016: 23), whose research in the greater Accra region revealed that most of the low-income earners live in compound houses in the country. Their reports further explain that the vast majority of the low-income renters prefer the compound houses because of the comparative advantages such as affordability and sharing of household facilities. This again confirms information from the Ghana population and housing censuses 2000 and 2010 reports, which demonstrated that, compared to the other housing typologies, sharing compound housing increased from $50 \%$ to approximately $70 \%$ between 2000 and 2010 (GSS, 2012: 39).

\subsection{Challenges associated with living in the study communities}

Respondents revealed that they face several challenges as a result of where they live. Table 3 indicates that in the three communities, market 
Table 3: Challenges when renting accommodation

\begin{tabular}{|c|c|c|c|c|c|c|c|c|c|}
\hline \multirow[b]{2}{*}{ Challenge } & \multirow[b]{2}{*}{ Category } & \multicolumn{2}{|c|}{ Akrobi } & \multicolumn{2}{|c|}{ Jensoso } & \multicolumn{2}{|c|}{ Zongo } & \multicolumn{2}{|c|}{ Total } \\
\hline & & $\begin{array}{c}\mathrm{F} \\
(\mathrm{N}=67)\end{array}$ & $\%$ & $\begin{array}{c}F \\
(N=94)\end{array}$ & $\%$ & $\begin{array}{c}F \\
(N=84)\end{array}$ & $\%$ & $\begin{array}{c}F \\
(N=245\end{array}$ & $\%$ \\
\hline \multirow{4}{*}{ Renting concerns } & Security & 10 & 35.8 & 23 & 24.5 & 6 & 7.1 & 39 & 15.9 \\
\hline & Availability of service & 24 & 14.9 & 2 & 2.1 & 12 & 14.3 & 38 & 15.5 \\
\hline & Market price & 4 & 6.0 & 26 & 27.7 & 44 & 52.4 & 74 & 30.2 \\
\hline & House facilities & 29 & 43.3 & 43 & 45.7 & 22 & 26.2 & 94 & 38.4 \\
\hline \multirow{4}{*}{$\begin{array}{l}\text { Family members } \\
\text { per room }\end{array}$} & Less than 2 & 8 & 12.0 & 5 & 5.3 & 10 & 11.9 & 23 & 9.4 \\
\hline & $2-5$ & 27 & 40.3 & 49 & 52.2 & 20 & 23.8 & 96 & 39.2 \\
\hline & $6-9$ & 18 & 26.8 & 22 & 23.3 & 30 & 35.7 & 70 & 28.5 \\
\hline & 10 or more & 14 & 20.9 & 18 & 19.2 & 24 & 28.6 & 56 & 22.9 \\
\hline \multirow{4}{*}{ Sanitation } & Bathroom & 33 & 49.3 & 21 & 22.3 & 22 & 26.2 & 76 & 31.1 \\
\hline & Toilet & 43 & 45.6 & 9 & 13.4 & 25 & 29.7 & 77 & 31.4 \\
\hline & Waste bins & 20 & 29.8 & 24 & 25.5 & 23 & 27.4 & 67 & 27.3 \\
\hline & Water & 5 & 7.5 & 6 & 6.4 & 14 & 16.7 & 25 & 10.2 \\
\hline \multirow{4}{*}{ Bathroom facilities } & Shared & 30 & 44.8 & 44 & 46.8 & 16 & 19.0 & 90 & 36.7 \\
\hline & \begin{tabular}{|l} 
Personal use \\
\end{tabular} & 21 & 31.3 & 4 & 4.3 & 7 & 7.1 & 31 & 12.7 \\
\hline & Open space & 5 & 7.5 & 7 & 7.4 & 27 & 32.1 & 39 & 15.9 \\
\hline & Self-constructed & 11 & 16.4 & 39 & 41.5 & 35 & 41.7 & 85 & 34.7 \\
\hline \multirow{4}{*}{ Toilet facilities } & Shared & 30 & 44.8 & 19 & 20.2 & 19 & 22.6 & 68 & 27.7 \\
\hline & Personal use & 4 & 6.4 & 4 & 4.3 & 7 & 8.3 & 15 & 6.1 \\
\hline & Public & 29 & 43.3 & 64 & 68.1 & 38 & 45.2 & 131 & 53.5 \\
\hline & None & 4 & 6.0 & 7 & 7.4 & 20 & 23.8 & 31 & 12.7 \\
\hline \multirow{4}{*}{ Kitchen facilities } & Shared & 1 & 1.5 & 3 & 3.2 & 5 & 6.0 & 9 & 3.7 \\
\hline & Personal use & 23 & 34.3 & 8 & 8.5 & 8 & 9.5 & 39 & 15.9 \\
\hline & Open space & 15 & 22.4 & 38 & 40.4 & 54 & 64.3 & 107 & 43.7 \\
\hline & Porch & 28 & 41.8 & 45 & 47.9 & 17 & 20.2 & 90 & 36.7 \\
\hline \multirow{4}{*}{ Waste disposal } & Burnt in open space & 45 & 67.3 & 15 & 16 & 3 & 3.6 & 63 & 25.7 \\
\hline & Dumping site & 7 & 10.4 & 55 & 58.2 & 43 & 51.2 & 105 & 42.9 \\
\hline & $\begin{array}{l}\text { Thrown in open } \\
\text { space }\end{array}$ & 8 & 11.9 & 2 & 2.1 & 1 & 1.2 & 11 & 4.5 \\
\hline & $\begin{array}{l}\text { Thrown in open } \\
\text { drains }\end{array}$ & 7 & 10.4 & 22 & 23.4 & 37 & 44.0 & 66 & 26.9 \\
\hline \multirow{4}{*}{ Quality of house } & Good & 27 & 40.3 & 8 & 8.5 & 10 & 11.9 & 45 & 18.4 \\
\hline & Satisfactory & 19 & 28.4 & 9 & 10 & 11 & 13.1 & 39 & 15.9 \\
\hline & Bad & 17 & 25.4 & 44 & 46.8 & 34 & 40.5 & 95 & 38.8 \\
\hline & Very & 4 & 6 & 32 & 34.0 & 29 & 34.5 & 66 & 26.9 \\
\hline \multirow[b]{2}{*}{ Privacy $(\mathrm{N}=151)$} & No privacy & 33 & 49.3 & 43 & 45.7 & 23 & 27.4 & 99 & 65.6 \\
\hline & $\begin{array}{l}\text { Not concerned } \\
\text { about privacy }\end{array}$ & 9 & 13.4 & 21 & 22.3 & 22 & 26.2 & 52 & 34.4 \\
\hline
\end{tabular}

price $(30.2 \%)$ and house facilities $(38.4 \%)$ are the main concerns that determine low-income tenants' decisions to rent accommodation.

\subsubsection{Security and safety}

In Table 3, although the availability of service $(15.5 \%)$ and security $(15.9 \%)$ was rated low on average, tenants in Akrobi rated security $(35.8 \%)$ as the major priority that determines their decision to rent accommodation. It must be noted that, although crime occurs in the Zongo and Jensoso communities, the respondents did not consider it a main concern in their decision to rent houses in the communities. The problem of insecurity among low-income renters in urban centres in Ghana has long been recognised as a growing and serious concern nature of the physical structures, coupled with poor sanitation, pose security threats and health risks to the residents. In Jensoso, the vast majority $(80.8 \%)$ of buildings' quality was rated bad (46.8\%) or very bad (34\%). These buildings are mostly the indigenous old compound houses that are weak for lack of maintenance. Three quarters (75\%) of the houses in Zongo are mostly physically very weak $(34.5 \%)$ or bad $(40.5 \%)$ and compacted with high levels of human congestion.

\subsubsection{Overcrowding}

Results in Table 3 indicate that the vast majority $(67.7 \%)$ of rental houses in the three communities have either two to five (39.2\%) or six to nine $(28.5 \%)$ family members occupying one room. Of the houses, $22.9 \%$ have ten or more family members occupying one room. These results show that rental houses are mostly overcrowded, according to UN-Habitat (2016: 12) standard, where a room is meant to accommodate at most three persons. The survey data revealed that $52.2 \%$ of the respondents in Jensoso have between 2-5 household members occupying a single room. In the Zongo community, most of the single rooms $(35.7 \%)$ are occupied by 6-9 household members. This agrees with Danso-Wiredu (2018: 16), Yankson (2012: 12), and Addo (2016: 23) whose work established that low-income renters in the Greater Accra region do not get enough sleeping space. Cooper and Jones (2008: 261) established that overcrowding has health implications for renters. Tenants put themselves at greater risk of getting infectious disease such as meningitis, and overcrowding contributes to mental stress and reduces people's sense of general well-being.

\subsubsection{Sanitation}

Results in Table 3 indicate that most of the rental houses in the three communities lack basic sanitation facilities. In communities where these facilities are present, they were either deteriorated or selfconstructed by renters and, in most cases, did not meet the standard 
of housing facilities prescribed by the Building Inspectorate Unit and the Environmental and Health Unit of the Assembly (Wenchi Municipal Assembly, 2018: 14). Overall, all three communities have more access to bathrooms $(31.1 \%)$ and toilets $(31.4 \%)$ than to waste bins $(27.3 \%)$ and clean water (10.2\%). Although $49.3 \%$ of the tenants in Akrobi have access to bathrooms, only $26.2 \%$ and $22.3 \%$ of the respondents from Zongo and Jensoso have access to standard bathrooms. The rest either take their baths in the open or construct temporal structures for use as bathrooms. While $16.7 \%$ of the tenants in Zongo have access to clean drinking water, only $7.5 \%$ and $6.4 \%$ from Akrobi and Jensoso have access to clean drinking water. Residents in these areas mostly resort to buying water from private water venders, which is expensive. Bad conditions or complete absence of sanitation facilities such as toilets, bathrooms, good drinking water, dustbins, and containers for waste collection, among others, make the sanitation situation a serious challenge for community members. This has significantly influenced the behaviour of some residents as they tend to dump their refuse in nearby drains or open spaces, due to the non-availability of dustbins or failure by the District Assembly to empty waste containers. Poor sanitation or lack of sanitation and no proper garbage disposal are health risks for tenants (De Vet et al., 2013; Mohammed \& Williams, 2013: 1152).

\subsubsection{Facilities}

Results in Table 3 on bathroom facilities show that, although $12.7 \%$ of the tenants have personal bathrooms, $36.7 \%$ of them share one bathroom, causing a very uncomfortable situation. While $34.7 \%$ of the tenants use their own self-constructed bathroom facilities, $15.9 \%$ are without bathing facilities and tenants depend on open space when the need arises. Bathing in open space exposes tenants to various degrees of insecurity. Women and children are exposed to all forms of attack, including verbal assault and rape (Boamah, 2010: 5).
Table 3 also shows that the three communities use four different types of toilet facilities. Although the vast majority $(53.5 \%)$ of the tenants use public toilets, $27.7 \%$ of tenants share one lavatory with other households within their homes and $6.1 \%$ have personal toilets in their houses, and $12.7 \%$ have no access to toilet facilities. In the three communities, most of the tenants (43.3\% Akrobi), (68.1\% Jensoso) and $(45.2 \%$ Zongo) use public toilet facilities, showing that, in Ghana, public toilets form a critical component of low-income tenants' lives. Toilet facilities is one of the basic facilities needed in a household or a rental unit. Having access to proper toilet facilities improves sanitation and environmental quality with its related benefits of healthy living.

Results on kitchen facilities show that many of the houses in the study communities did not have proper kitchens. Although 15.9\% of the tenants have access to their own kitchens, 9\% share kitchens with other families. While $36.7 \%$ of the tenants use porches as kitchen facilities, the majority of them $(43.7 \%)$ use open spaces for cooking. Some landlords/ladies have converted kitchens into rooms for hiring, leaving tenants with no option but to find their own temporal structures (porches) as kitchens, as results show for Akrobi (41.8\%) and Jensoso (47.9\%). Sometimes, these porches also serve as rooms for tenants with large families. Those who cannot afford to construct their own structures resort to cooking in open spaces, as results show for Jensoso (40.4\%) and Zongo (64.3\%). Cooking in open spaces (see Figure 3) makes it difficult to prepare food, especially when it is raining. The vast majority of households use firewood and charcoal for cooking. This finding, which is not different from that in most of the smaller towns and rural areas, shows how the forest vegetation is under threat in the country.

The results are similar to the studies by Ofori (2020) and Amenyah \& Fletcher (2013) which indicate that most of the rental houses occupied by low-income renters are associated with a lack of basic housing infrastructure and have poor housing facilities. Tenants are inconvenienced when facilities such as toilets, bathrooms, pipes and kitchens are not available or are not located in the house. The results also agree with the findings of Danso-Wiredu (2018: 16), Addo (2016: 23), and Owusu (2010: 9), which revealed that basic facilities in low-income areas are highly inadequate in Agbogbloshie, old Fadama, James Town as well as Sabon Zongo and other vulnerable communities in Accra, making life difficult for renters in such areas.
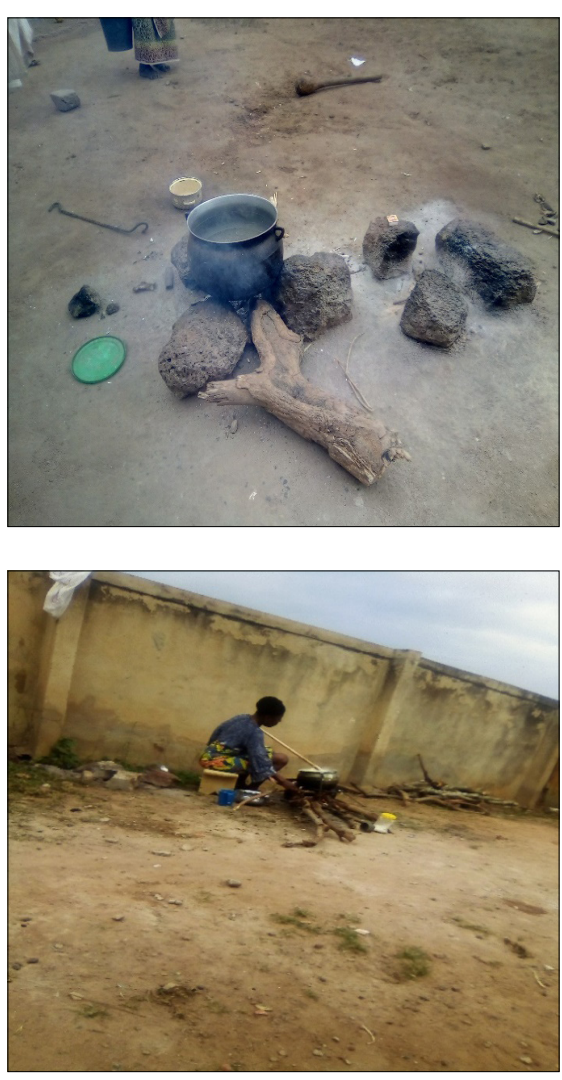

Figure 3: Cooking in open space in Jensoso and Zongo

Source: Image by authors, 2020

\subsubsection{Waste disposal}

Results in Table 3 show that, although the majority $(69.8 \%)$ of the tenants use dumping sites (42.9\%) and open drains $(26.9 \%)$ for waste disposal, $25.7 \%$ burn waste in open spaces, and only $4 \%$ throw waste in open spaces. Tenants indicated that waste management in their areas of residence was a big challenge. Tenants cannot afford waste bins and the Assembly takes over a month to collect waste from 
the bins and the public dumping sites in the communities. Improper waste collection and disposal such as dumping in open drains (Zongo $44 \%$ ) leave tenants at risk of health problems. These results are similar to those of the studies by de Vet et al., (2013) and Mohammed and Williams (2013: 1152), who stated that dumping of waste, including raw sewage in drains and open gutters as way of garbage disposal, results in blocked drains with stagnant water serving as breeding grounds for mosquitoes with the resultant malaria.

\subsubsection{Privacy}

Table 3 shows that the vast majority $(65.6 \%)$ of the tenants in low-income rent houses do not have privacy.

Respondents complained that lack of appropriate facilities such as cooking space, household facility sharing, sleeping in the same rooms with all family members, result in the performance of their private activities in public. Of the respondents from Akrobi, Jensoso and the Zongo, $49.3 \%$, $45.7 \%$ and $27.4 \%$, respectively, alluded to the fact that they were unable to do anything secret as couples or families because of their sharing the facilities, including sleeping rooms. The findings are in line with the work of Gwandure (2009: 30), who argued that violation of personal space could lead to psychological trauma. Researchers such as Yankson (2012: 12), Addo (2013: 19), Danso-Wiredu (2018: 16) and Wrigley-Asante et al. (2019: 25) confirm in their studies that, where the majority of low-income renters in communities such as Old Fadama, Agbogbloshie, Nima, Chorkor and other vulnerable places where communities mostly compete for space and six or more people stay in a single room, there is no right to privacy. The report also agreed with Graham et al.'s (2006) findings, which disclose that people who live in overcrowded accommodation or housing with shared facilities put themselves at greater risk of getting infectious diseases.

\subsubsection{Quality of rental housing}

Results in Table 3 show that respondents rated the quality of rental housing in the three study communities as 'bad' to 'very bad'. Although $40.3 \%$ of the respondents from Akrobi rated their houses as 'good', respondents rated $80.8 \%$ of the houses in Jensoso as 'bad' $(46.8 \%)$ or 'very bad' (34\%); in Zongo, $75 \%$ of the houses were rated either 'bad' $(40.5 \%)$ or 'very bad' (34.5\%). Respondents stated that these poor-quality structures cannot protect tenants from a range of hazards such as harsh weather conditions, thus posing a danger to their lives. Adu et al. (2016) confirm these findings, which reveal that low-income residents in the Wa Municipality who reside in mud houses are living in perpetual fear of their rooms collapsing on them during the rainy season.

\subsection{Tenants' coping strategies}

In their quest to survive in the midst of the challenges, tenants have adopted a number of interventions to cope with their problems. Although some of the coping strategies are life threatening, the respondents can only manage the situation. Table 4 shows an almost equal distribution for the coping measures adopted by respondents with manage the situation (29.4\%), conversion of their porches and kitchens to bedrooms for other family members (25.3\%); others also decide to allow their children, especially teenagers, to sleep with their friends and families in town (20\%).

The study indicated that a good number of tenants in Akrobi, Zongo and Jensoso (34.3\%, 24.6\% and $30.9 \%$, respectively) mentioned that they could not do anything about the situation other than to manage it in its current form and cope. The respondents revealed that most of the parents in Jensoso (37.2\%) and Zongo (12.9\%) either allowed their grown-up children (adolescents) to sleep with their friends in town or sent them to stay with other people as a way of decongesting their rooms. Again, 36.7\%, 25.4\% and $15 \%$ of the tenants in Jensoso, Zongo and Akrobi, respectively, resort to residential adaptation adjustments, thus converting their porches into bedrooms at night, although, sometimes, the same porches are used as kitchens during the day. Those who can afford it have also constructed temporal showers in their rented houses, since the landlords/ladies refused to provide such facilities.

According to the respondents, most of the parents worry about where their teenage children spend the night with their friends or other family members. Careful observations of activities in the communities indicate that most of the young girls who stay away from home, due to inadequate sleeping spaces, end up spending the night with their boyfriends and most of them become pregnant at tender ages, while the boys, on the other hand, adopt deviant behaviours such as smoking and other antisocial activities. The findings are affirmed by Owusu (2010: 9), Yankson (2012: 12), Adu et al. (2016: 17), Danso-Wiredu (2018: 16), and Wrigley-Asante et al. (2019: 25) whose research revealed that low-income earners in Old Fadama, Agbogbloshie, Chorko, Nima, Sabon Zongo and other vulnerable communities in the country resort to sharing cooking spaces, bathrooms and toilet facilities, daily collective rental payment, conversion of porches into bedrooms, and staying with friends as a coping mechanism.

Table 4: Coping strategies

\begin{tabular}{|l|c|c|c|c|c|c|c|c|}
\hline \multirow{2}{*}{\multicolumn{1}{c|}{ Coping strategy }} & \multicolumn{2}{c|}{ Akrobi } & \multicolumn{2}{c|}{ Jensoso } & \multicolumn{2}{c|}{ Zongo } & \multicolumn{2}{c|}{ Total } \\
\cline { 2 - 10 } & $\begin{array}{c}\mathrm{F} \\
(\mathrm{N}=67)\end{array}$ & $\%$ & $\begin{array}{c}\mathrm{F} \\
(\mathrm{N}=94)\end{array}$ & $\%$ & $\begin{array}{c}\mathrm{F} \\
(\mathrm{N}=84)\end{array}$ & $\%$ & $\begin{array}{c}\mathrm{F} \\
(\mathrm{N}=245\end{array}$ & $\%$ \\
\hline Manage & 23 & 34.3 & 29 & 30.9 & 20 & 24.6 & 72 & 29.4 \\
\hline No option & 24 & 35.8 & 16 & 16.9 & 22 & 25.8 & 62 & 25.3 \\
\hline Sleep with friends & 3 & 4.5 & 35 & 37.2 & 11 & 12.9 & 49 & 20.0 \\
\hline $\begin{array}{l}\text { Convert kitchens and porches } \\
\text { to rooms }\end{array}$ & 17 & 25.4 & 14 & 15.0 & 31 & 36.7 & 62 & 25.3 \\
\hline
\end{tabular}




\section{CONCLUSIONS AND POLICY IMPLICATIONS}

Although housing is a basic necessity of life, over half of the population in Ghana lives in poor housing conditions, where they have hardly any or no access to adequate sanitary facilities, household facilities, and community infrastructure. This study set out to assess how poor housing affects low-income renters and the various coping mechanisms they adopt, in order to survive their challenges. The study focused on Wenchi Municipality in the Bono region of Ghana. This study is unique, as many studies on low-income housing in the country focus on cities and large towns, whereas this study investigated the situation from the perspectives of a smaller town, Wenchi.

The study theoretically employed Morris and Winter's housing adjustment theory, with key findings from the three communities under study have postulated a great relationship between the set-up of the three communities and the theory as used in other countries. The theory explains that the nature of a society sometimes determines its inhabitants. For instance, well-organised communities with proper securities and good environmental conditions sometimes set a standard for themselves and these standards do not give allow people who fall below such standards to settle there. On the other hand, communities with weak infrastructure, poor environmental and sanitation conditions relax their restrictions to entry and exit in most cases. More importantly, when the entry is fluid, it allows alterations to the existing housing make-ups to suit the needs of household members. This is what the findings revealed in the study communities in a smaller town in Ghana.

The study revealed that the types of housing available for rent in the communities were compound houses, compound single storey, compound multi-storey, detached and semi-detached. The results from the study indicated that the compound houses were the most predominant form of rent among the tenants in the communities. Based on this, the communities identified for the study were classified into three groups, namely indigenous society, migrants and the mixed or middle-income society. Key results from the field have established that compound housing is the most common housing type in the three communities; the traditional old mud housing system was common in the Jensoso community, which is the indigenous community. Evidence from the field attested to the fact that tenants in this community live in fear, due to the poor physical nature of their houses. On the other hand, kiosks and all forms of makeshift structures and uncompleted buildings were also commonly found in the Zongo community, which is a migrant community. The common challenges of the housing system in these two communities were inadequate sanitation and poor household facilities. Although the housing morphology in Akrobi (the mixed community) was better than that in the other two communities, there were still pockets of poor houses in that area. The study also found that tenants were primarily vulnerable, because their landlords, as property owners, possess tremendous power over them. Another factor that had an effect on tenants was no reciprocal value for money paid for rent. Although they expressed their concern of not getting value for the money they paid for the rooms, they often did not have much to say. This was compounded by the absence of the Rent and Control Department in the Municipality.

Results from the field have confirmed that, due to housing deficits and other factors, tenants were unable to afford decent and affordable housing for their families. These housing constraints and deficiencies compelled the vast majority of tenants in the study communities to seek alternative solutions to their housing problems. Mediation factors such as changes made based on income levels of tenants; alteration of buildings; dependent on community public facilities such as toilet and shower; cooking outside using available open spaces at the compound and turning porches into bedrooms at night were some of the coping strategies used by tenants to affirm the right to the city of all dwellers. The study confirmed the findings in the literature on the challenges low-income renters face in Ghanaian cities and large towns. This also adds to the existing knowledge that smaller towns experience similar problems with different alternative solutions. The study made the following policy recommendations. The Municipality should establish and strengthen the Rent Control, which is mandated to implement and monitor the rent sector so that it can implement The Rent Act of 1963 and the Rent Control Law of 1986's guidelines on the housing rental system in Ghana to protect the interest of tenants. Prominent among these guidelines is the need for landlords/ladies to provide toilet and other household facilities for their tenants. Apart from providing an enabling environment to the private sector to build houses on a commercial basis (these are usually beyond the reach of the poor), the state should build social housing for the poor in the form of decent compound housing.

\section{REFERENCES}

\section{ABOAGYE, A.Q.Q. \& SARPONG- KUMANKOMA, E. 2011. Housing and construction finance, deposit mobilisation and bank performance in Ghana. Journal of Property Research, 28(2), pp. 151-165. https://doi.org/10.10 80/09599916.2010.538478}

ADDO, I.A. 2013. Perceptions and acceptability of multihabitation as an urban low-income housing strategy in Greater Accra Metropolitan

Area, Ghana. Urban Forum, 24(4), pp. 543-571. DOI 10.1007/s12132-0139192-2 Springer

ADDO, I.A. 2016. Assessing residential satisfaction among lowincome households in multi-habited dwellings in selected low-income communities in Accra. Urban Studies, 53(4), pp. 631-650. https://doi. org/10.1177/0042098015571055 
ADU, M.P., ABEDI, J.O., GYAN, H.B. \& JANNETH, J.J. 2016. A study of residential housing in Ghana's lowincome urban areas in Wa Municipality. African Journal of Geography and Regional Planning, 3(4), pp. 240-254.

AMENYAH, I.D. \& FLECHER, E.A. 2013. Factors determining residential rent price. Asian Economic and Finance Review, 3(1), pp. 39-50.

ANDREASEN, J. \& ANDERSEN, J.E. 2006. The demise of compound houses: Consequences for the lowincome population in Kumasi, Ghana. Richs Research, 6(8), pp. 1-43.

APPIAH-KUSI, G. 2015. The role of the informal sector in housing provision in Kumasi. Unpublished Master's thesis. Kwame Nkrumah University of Science and Technology, Ghana.

ARKU, G., LUGINAAH, I. \& MKANDAWIRE, P. 2012. You either pay more advance or you move out; landlord/ladies and tenants dilemmas in the low-income housing market in Accra, Ghana. Urban Studies, 49(14), pp. 3177-3193. https://doi. org/10.1177/0042098012437748

BALLESTEROS, M.M. 2004. Rental housing for urban low-income households in the Philippines. Discussion Paper Series, pp. 1-21.

BELSKY, E.S. \& DREW, R.B. 2007. Taking stock of the nation's rental housing challenges and a half century of public policy responses. Harvard: Joint Center for Housing Studies of Harvard University.

BOAMAH, N. 2010. Housing affordability in Ghana: A focus on Kumasie and Tamale. Ethiopian Journal of Environmental Studies and Management, 3(3), pp.1-11. https://doi. org/10.4314/ejesm.v3i3.63958

BRYMAN, A. 2012. Social research methods. $4^{\text {th }}$ edition. New York: Oxford University Press.

BUJANG, B., AFRANE, E., ARIFFIAN, A., SHUAIBU, H. \& KASIM, I. 2016. Major factors causing housing deficit in Ghana. Developing Country Studies, 6(2), pp. 139-147.

CHARLES-COLL, J.A. 2011. Understanding income inequality: Concept, causes and measurement. International Journal of Economics and Management Sciences, 1(3), pp. 17-28.
CHIWENGA, A. 2019. Low-income housing problems and low-income housing solutions: Opportunities and challenges in Bulawayo. Journal of Housing and the Built Environment, vol. 34, pp. 927-938. https://doi. org/10.1007/s10901-019-09676-w

COOPER, J. \& JONES, K. 2008.

Routine maintenance and sustainability of existing social housing. In: Proceedings of the CIB W070 Conference in Facilities Management, 16-18 June, Heriot Watt University, Edinburgh, pp. 361-368.

DANSO-WIREDU, E.Y. 2018. Housing strategies in low-income urban communities in Accra. Geojournal, 83(4), pp. 663-677. https://doi. org/10.1007/s10708-017-9792-9

DANSO-WIREDU, E.Y. \& MIDHENE, E. 2017. Slum upgrading in developing countries: Lessons from Ghana and Kenya. Ghana Journal of Geography, 9(1), pp. 88-108.

DANSO-WIREDU, E.Y. \& POKU, A. 2020. Family compound housing system losing its value in Ghana: A threat to future housing of the poor. Housing Policy Debate, 30(6), pp. 1016-1032. https://doi.org/10.1080/ 10511482.2020.1792529

DZANGMAH, H.T. 2012. Prospects and challenges of rental housing in Greater Accra region. Unpublished Master's thesis. Kwame Nkrumah University of Science and Technology, Ghana.

EYISI, D. 2016. The usefulness of qualitative and quantitative approaches and methods in researching problemsolving ability in science education curriculum. Journal of Education and Practice, 7(15), pp. 91-100.

\section{GSS (GHANA STATISTICAL}

SERVICE). 2012. The 2012 population and housing census. District analytical report: Wenchi Municipality.

\section{GSS (GHANA STATISTICAL}

SERVICE). 2014. Ghana Demographic and Health Survey 2014. Rockville, Maryland, USA: GSS, GHS, and ICF International.

GILBERT, A. 2004. Helping the poor through housing subsidies: Lessons from Chile, Colombia and South Africa. Habitat International 28(1), pp. 13-40. https://doi.org/10.1016/ S0197-3975(02)00070-X
GRAHAM, H., EMERSON, E., HATTON, C., LLEWELLYN, G. \& BLACKER, J. 2006. Socio-economic position, household composition, health status and indicators of the wellbeing of mothers of children with and without intellectual disabilities. Journal of Intellectual Disability Research, 50(12), pp. 862-873. https://doi. org/10.1111/j.1365-2788.2006.00900.x

GWANDURE, C. 2009. Life with limited privacy due to housing challenges: Impact on children's psychological functioning. African Safety Promotion: A Journal of Injuryand Violence Prevention, 7(1), pp. 30-49. DOI: 10.4314/asp.v7i1.54601

HAWKINS, R. \& STEWART, S. 2002. Changing rooms: The impact of adaptations on the meaning of home for a disabled person and the role of occupational therapists in the process. British Journal of Occupational Therapy, 65(2), pp. 81-87. https://doi. org/10.1177/030802260206500206

HYDE, S. 2018. The effects of the rent burden on low-income families. Monthly Labor Review, (March), pp.1-2.

IMRIE, R. \& HALL, P. 2003. Inclusive design: Designing and developing accessible environments. London: Taylor \& Francis. https://doi. org/10.4324/9780203362501

KOJO, R. \& PASCHAL, N. 2018. Urban population growth and environmental sustainability in Nigeria. Journal of Empirical Studies, 5(1), pp. 12-19. https://doi.org/10.18488/ journal.66.2018.51.12.19

KREJCIE, R.V. \& MORGAN, D.W. 1970. Determining sample size for research activities. Educational and Psychological Measurement, 30, pp. 607-610. https://doi. org/10.1177/001316447003000308

KRIEGER, J. \& HIGGINS, D.L. 2002. Housing and health: Time again for public health action. American Journal of Public Health, 92(5) pp. 758-68. doi: 10.2105/ajph.92.5.758

LONARDONI, F. \& BOLAY, J.C. 2016. Rental housing and the urban poor: Understanding the growth and production of rental housing in Brazilian favelas. International Journal of Urban Sustainable Development, 8(1), pp. 4967. https://doi.org/10.1080/19463138.2 015.1102141 
LUGINAAH, I., ARKU, G. \& BAIDEN,

P. 2010. Housing and health in Ghana: The psychosocial impacts of renting a home. International Journal of Environmental Research and Public Health, 7(2), pp. 529-545. https://doi. org/10.3390/ijerph7020528

MAGINA, F.B. 2016. Housing market in redeveloping inner-city areas in Dar Es Salaam: Supply dynamics and their effects on the urban fabric. Unpublisned PhD. Technische Universität Dortmund, Germany.

MARA, D., LANE, J., SCOTT, B. \& TROUBA, D. 2010. Sanitation and health. PLoS Med, 7(11): e1000363. https://doi.org/10.1371/journal. pmed.1000363

MINISTRY OF FINANCE. 2018. The Wenchi Municipal Assembly. Composite Budget for 2019 to 2022. Accra, Ghana.

MOHAMMED, S.A. \& WILLIAMS, D.R. 2013. Racism and health, I: Pathways and scientific evidence. American Behavioural Scientist, 57(8), pp. 1152-1173. https://doi. org/10.1177/0002764213487340

MORRIS, E.W. \& WINTER, M. 1975. A theory of family housing adjustment. Journal of Marriage and the Family, 37(1), pp. 79-88. https://doi. org/10.2307/351032

MORRIS, E.W. \& WINTER, M. 1978. Housing, family, and society. New York: Wiley.

MWRWH (MINISTRY OF WATER RESOURCES, WORKS AND HOUSING). 2015. Draft National Housing Policy, 2012. Accra: Government of Ghana.

NAOUM, S.G. 2013. Dissertation research and writing for construction students. $3^{\text {rd }}$ edition. Oxford:

Butterworth-Heinemann. https://doi. org/10.4324/9780203720561

NSIAH, M.D. 2017. Assesing rental housing delivery in Ghana: The Case of Abeka, a suburb of Accra Metropolitan assembly. Unpublished Masters thesis. Department of Geography and Regional Planning, College of Humanities and Legal Studies University of Cape Co.

ODURO-FRIMPONG, J. 2011. Sakawa: On occultic rituals and cyberfraud in Ghanaian popular cinema. [Online]. Availabe at: <http://www. media-anthropology.net/file/frimpong_ rituals_cyberfraud.pdf> [Accessed: 18 November 2020].
OFORI, P. 2019. Efficiency of rental housing in mitigating housing challenges in Ghana: The case of Old-Tafo semi-detached houses in Kumasi Township. Ethiopian Journal of Environmental Studies \& Management, 12(2), pp. 167-180. https://ejesm.org/ doi/v12i2.5

OFORI, P. 2020. Housing poverty in developing countries: Challenges and implications for decent accommodation in Swedru, Ghana. Acta Structilia, 27(2), pp. 57-92. doi: 10.18820/24150487/as27i2.3

OTENG-ABABIO, M. 2016. Beyond poverty and criminalization: Splintering youth groups and 'conflict of governmentalities' in urban Ghana. Ghana Journal of Geography, 8(1) Special Issue, pp. 51-78.

OWUSU, G. 2010. Social effects of poor sanitation and waste management on poor urban communities: $A$ neighborhood-specific study of Sabon Zongo, Accra. Journal of Urbanism: International Research On Placemaking and Urban Sustainability, 3(2), pp. 145-160. https://doi.org/10.108 0/17549175.2010.502001

OWUSU-ANSAH, A. 2012. Examination of the determinants of housing values in urban Ghana and implications for policy makers. Journal of Africa Real Estate Research, 2(1), pp. 58-85.

PALLANT, J. 2013. SPSS survival manual: A step-by-step guide to data analysis using IBM SPSS. $5^{\text {th }}$ edition. Crows Nest, Australia: Allen and Unwin.

PEPPERCORN, I. \& TAFFIN, C. 2013. Rental housing lessons from international experience and policies for emerging markets. Washington, DC: World Bank. https://doi. org/10.1596/978-0-8213-9655-1

QUERCIA, R.G. \& ROHE, W.M. 1993. Models of housing adjustment and their satisfaction and the propensity to move: A replication of the housing-adjustment model. Housing and Society, 15(1), pp. 41-55. https://doi.org/10.1080/0888 2746.1988.11430005

SINAI, I. 2001. Moving or improving: Housing adjustment choice in Kumasi. Housing Studies, 16(1), pp. 97-114. https://doi. org/10.1080/02673030020015146

UN-HABITAT. 2003. The challenge of the slums: Global report on human settlements. United Nations Centre for Human Settlements. London: Earthscan.
UN-HABITAT. 2011. Global report on human settlements 2011: Cities and climate change. United Nations Human Settlements Program. London: Earthscan.

UN-HABITAT. 2016. World cities report: Urbanization and development - Emerging futures. HS Number HS/038/16E. Nairobi, Kenya: UN-Habitat.

DE VET, R., VAN LUIJTELAAR, M.J., BRILLESLIJPER-KATER, S.N., VANDERPLASSCHEN, W., BEIJERSBERGEN, M.D. \& WOLF, J.R. 2013. Effectiveness of case management for homeless persons: A systematic review. American Journal of Public Health, 103(10), e13-e26. doi: 10.2105/AJPH.2013.301491

WENCHI MUNICIPAL ASSEMBLY. 2018. Housing codes: Building Inspectorate Unit and the Environmental and Health Unit of the Assembly Wenchi Municipal Assembly, pp. 1-23.

WRIGLEY-ASANTE, C., FRIMPONG, L.K., AMU, J.T., OWUSU, G. \& OTENG-ABABIO, M. 2019. Determinants of perceived insecurity in a low-income neighborhood in Accra, Ghana. Journal of Urbanism: International Research on Placemaking and Urban Sustainability, 12(4), pp. 476-495. https://doi.org/10.1080/ 17549175.2019.1635189

WRIGLEY-ASANTE, C., OWUSU, G., OTENG-ABABIO, M. \& OWUSU, A.Y. 2016. Poverty and crime: Uncovering the hidden face of sexual crimes in urban low-income communities in Ghana. Ghana Journal of Geography, 8(1), pp. 32-50.

YANKSON, P.W.K. 2012. Rental housing and tenancy dynamics with particular focus on low-income households in Greater Accra Metropolitan Area. In: ArdayfioSchandorf, E. \& Yankson, P.W.K. (Eds). The mobile city of Accra: Urban families, housing and residential practices. Dakar: CODESRIA, pp.183-206.

YANKSON, P.W.K. \& GOUGH, K.V. 2014. Urban low-income housing in Ghana. In: Bredenoord, J., Van Lindert, P. \& Smets, P. (Eds). Affordable housing in the urban Global South. London: Routledge, pp. 407-420. 